Миланка Бабић Вукадинов*

Библиотека града Београда
821.581(497.11)

https://doi.org/10.18485/melissa.2018.17.1.ch11

Оригинални научни рад

Примљен: 06.08.2018

Прихваћен: 11.09.2018.

\title{
ТРЕШЊИН ЦВЕТ У СРПСКОМ ОК(Н)У
}

\section{Сажетак}

Прве речи о кинеској књижевности у српској култури исписане су на црквенословенском језику 1841. године и објављене у Сербском народном листу (Сербскій народный листь), у Будиму. У 19.веку (1843. и 1844.године) објављена су још два краћа текста о кинеској књижевности, да би тек 1923.године, преко Париза, са Антологијом кинеске лирике Милоша Црњанског српска култура имала узбудљив и прожимајући сусрет са културним стваралаштвом кинеског духа. До Другог светског рата само још две антологије кинеске књижевности биле су пред нашим читаоцима и то: Лирика жутог Истока Златка Горјана (1932) и Кинеске и јапанске бајке (1934).

Кључне речи: кинеска књижевност на српском језику; Кина- српски путопис; Милош Црњански

Српска библиографија ${ }^{1}$ открива податак да су први забележени трагови о кинеској култури у српским новинама 40-тих година 19 века.

У Будиму, исписано је девет кинеских (хінезске) пословица на црквенословенском језику у «Сербском народном листу» (Сербскій народный листь $)^{2}$ 1841. године. Пословице су биле, као код сваког народа, есенција његове мудрости: „Два срца су близу кад порока међу њима нема“. Или, „Добри рачун чине добре пријатеље“; као и: „Лепе речи и лажна игра варају младо и старо“.

\footnotetext{
* Библиотека града Београда, Кнеза Михаила 56, Београд 11000 milabv@gmail.com

1 Прилози за израду кинеске библиографије, приредили: Здравка Радуловић, Бранислав Ристић, Небојша Ковачевић, Београд: Народна библиотека Србије, 2014

2 Сербскій народный листь, Будим: Ө. Павловићъ (Теодор Павловић), число 37, 11.септембар 1841, стр.296
} 
У другом тексту писано је о „списатељству“ у Кини и објављен је у додатку „Подунавка“, који је излазио у „Србским новинама“, 6. марта $1843 .^{3}$

У „Списательство у Хини“ тврди се да списатељи (књижевници) припадају највишој класи грађанства и открива да се сваке године у провинцијама, а сваке треће године у Пекингу, одржавају „подобне испыт" како би се народ образовао, јер у тим разговорима, слично као у античкој Грчкој, „множина честолюбивы наученика скупи“. царство је као један велики универзитет, а ко прође све испите, буде одликован, то јест указују му се посебне почасти. Чланови највишег „књижевногь достоинства могу на капи носити извъстный бълый каменъ“, што је била изузетна част. Кинези много читају, штампарије „силу посла имаю“, трговина са књигама је исплатива. Богатије породице „имаю свое кньижнице, а влада има свое сбирке“". Те „сбирке“ тј. библиотеке су већ толико бројне да имају и каталоге, неки су само са насловима књига и именима аутора, а има и каталога у коме је записан кратки садржај дела. Царска библиотека у Пекингу има оба каталога. И текст се завршава чуђењем: „Само едноме незнамо узрока; Хина као да никакве цензуре нема. ${ }^{\prime 6}$

Како су „Србске новине“ излазиле у Београду, који је још увек турски град, Срби се још боре за независност, несумњиво је да су чињенице изнете у тексту плод прочитаних текстова у новинама које су илазиле у Будиму или Пешти, где је било путника који су посетили Кину и донели приче о њој. Али изнете чињенице су пажљиво биране, јер у каснијим путописима, које су писали Срби, који су посетили Кину, оставили су сличне податке: утицај и значај учених људи, поштовање које књижевници и сликари имају у друштву, лепота велике земље, необична гардероба Кинеза, европске четврти у кинеским градовима, тежак живот сиромашних слојева, посебно су се осврнули на нељудско коришћење рикши...

„Подунавка“, као додатак „Србским новинама“ у 1844. години донела је више текстова о Кини, од њених пословица до начина управљања земљом.

\footnotetext{
3 Србске новине, додатак Подунавка, Београд, бр. 10, 6. март 1843., стр.34

4 Исто, стр.34

5 Исто, стр.44

6 Исто, стр.44
} 
У броју 17. од 22. априла 1844. један од сарадника Димитрије Аврамовић доноси текст у љубазности Кинеза, о етикецији у друштву која нама; Европљанима, често буде претерана.

Већ споменути Аврамовић пише и текст: „Обожаванъ Наполеона у едној хинезкой богомольи“ ${ }^{\prime 1}$ у коме стоји да је неки Енглез донео кип са Наполеоновим ликом у кинеску богомољу, где су му се клањали и Кинези, што наш новинар тумачи као израз оне љубазности и етикеције тако карактеристичне за овај народ.

У броју 23. од 3. јуна 1844. читамо неколико кинеских пословица тј. „хинезка изречения“: „Човек може рибу и у дубокој води мрежом уловити, и орла у лету устрелити, али човечје срце на стопи удаљености не може познати“. Или: „Сви су људи од природе једнаки, али их васпитање чини неједнаким“.2

„Пештанско-будимска скоротеча“ у фебруарском броју 1844. године ${ }^{3}$ пише о Кини као загонетној земљи: то је земља са 1600 вароши (мањи градови), 1190 градова, преко 2800 храмова (цркава), преко 2600 манастира, држава већа од највећих земаља Европе, 338 милиона људи - има више него цела Европа... Детаљно се објашњава административна контрола земље. Оно што изазива пажњу писца текста је да на свакој кинеској кући мора да стоји таблица на којој је исписано колико душа живи у том домаћинству, колико стоке има јер на основу тога се наплаћује порез. Ништа се не може сакрити и зато су Енглези и релативно лако владали земљом коју су поделили у 18 провинција...

Текстови у српским новинама, више цртице него прави новинарски текстови, нису приближили српском читаоцу ову далеку земљу. А и оно шо је стизало до Србије било је из других, страних извора. Први поуздани извори су били српски путници који су из разноразних разлога стизали до царства жада, пустиње Гоби и Великог зида. И то већ на самом крају 19 века, пре сусрета са књижевношћу и сликарством, директни контакти Срба са Кином били су оне важне карике које су пробудиле знатижељу сензибилних уметника да открију тајне које се крију иза Великог зида.

1 Србске новине, додатак Подунавка, Београд, бр.18, 29. април, 1844, стр.72

2 Србске новине, додатак Подунавка, Београд ,бр23, 3.јуна 1844, стр.92

3 Хінезска загонетка, Пештанско-будимскій скоротеча, Будим: Димитрій Івановичь, бр.11, 6. фебруар 1844, стр.58 
Наши путници су постајали и путописци у жељи да открију тајне, лепоте, егзотику, свакодневницу Поднебеског царства и ти путописисусрети Срба са овом далеком земљом, почињу да се објављују од 1894.године.

На почетку тог сусрета Срба и Кинеза беше један српски великан на двору руских царева и овде га спомињемо као значајно име руске дипломатије, чија су дела писани на руском. Први Србин који је писао о Кини и Кинезима је гроф Сава Владиславић, дипломата код Петра Великог и Катарине Велике. То су дипломатски списи, записи дипломате који се среће са врхом кинеске власти и његова запажања су човека који се грчевито, али успешно бори за интересе своје нове домовине, Русије. Гроф Владиславић је записан и у руској и кинеској историји, јер је одредио границу између ове две земље која важи и данас.

Први путопис у српској књижевности у којој се говори о Кини написао је Милан Јовановић Морски, лекар и књижевник. Он је 1894/95. године у Српској књижевној задрузи објавио своју путописну књигу „Тамо амо по истоку (Црте)“1. Потом су се низали: српски војници-официри који су из заробљеничких логора у Русији, путовали до Србије преко Кине и оставили драгоцена сведочанства: Јован Д.Миланковић, српски дипломата на служби у Русији, у време Октобарске револуције; Озрен Ј.Суботић, извештач Правде, 1932.године објављује путописе „Из жутог царства“; пуковник др Влада Станојевић, Александар Ђурић, Милутин Велимировић, нешто касније и његова братаница, рођена у Кини, Јелена љаља Велимировић, затим многи интелектуалци као што су Паја Радосављевић, Живко Петковић....

Они су својим књигама, новинским текстовима тога времена приближили свакодневни живот Кинеза, али оно суштински што чини дух овог народа, откривано је тек са превођењем његове поезије и представљањем сликарства.

Антологија Златка Горјана „Лирика жутог Истока“ објављена je 1932. године у Загребу, и обухвата преводе кинеске поезије од

1 Поднебеско царство: Срби о Кини 1725-1940 (путописи и чланци), приредио Радосав Пушић, Београд: Чигоја штампа, 2006, стр.33 
најстаријих времена, од Конфучија до класичног доба, највећих Ли Таи Пеа и Ту Фуа и завршава са Ли Зонг Флуом. Преводи су са немачког , енглеског и француског. Горјан пише да је кинеска поезија, врло компликована, не само за превођење: „...из замршених сликарских проблема писма и језика ствара се, по сликарским и музикалним законима, ритмика, која нема готово ничега заједничког са ритмиком европског пјесништва. Суптилно израђени, често протурјечни паралелизам у ријечима, мислима, штовише, и у орнаментално израђеним словима - све су то особине кинеске пјесме."

Први значајан сусрет са књижевношћу Далеког истока, тј. кинеском и јапанскомпоезијом, који је и данас незаобилазан, су антологије поезије које је објавио Милош Црњански. Године 1923. Црњански објављује „Антологију кинеске лирике“3, а 1928. антологију „Песме старог Јапана“.

„Антологија кинеске поезије“ је први рад такве врсте код нас. Песме које је писац „Сеоба“ и „Суматре“ унео у антологију су препеви са француског ${ }^{4}$, којима је био углавном задовољан. Имао је замерку да ти преводи „пате, често, од исте болести: европеизације. Безбрижно су улепшани, пофранцужени.... Иде се тако далеко, да се кажу речи које Кинез не може рећи; дају се слике без кинеске боје и дешава се да употребе имена обичаја, биља, која тамо и не постоје."

Важно је имати и такву антологију „да бисмо показали и најдаље, прастаре слике, мисли, утицаје и везе духа, које су, у своме вечном кружењу, кроз живот, могле стићи и до нас...."6

У предговору „Антологије кинеске лирике“ који је Црњански назвао „Моја антологија кинеске лирике“: „Јапански, још више кинески лиризам имао је огромног по моме мишљењу, утицаја, непримећеним странпутицама, у задње доба на европски, а код нас

2 Zlatko Gorjan: Lirika žutog istoka, Zagreb, 1932, str.8

3 Милош Црњнаски: Антологија кинеске поезије, Чачак: Градац, 2004 (Антологија је објављена у издавачкој кући Напредак)

4 Тих 20-година 20. века Црњански је радио у Народној библиотеци у Паризу и тамо је нашао најбоље преводе са кинеског, јер је француска синологија једна од најбољих. Песник се највише користио књигама белгијског академика Харлеза.

5 Miloš Crnjanski: Antologija kineske lirike, Čačak: Gradac, 2004, стр.47

6 Исто, стр.45 
је потпуно непознат“. Песник „Суматре“ и „Ламента над Београдом“ тврди да резултат тих мислилаца „неизмерно давно, врхунац свега прозрачног, мирног, вечног, етеричног, до чега дух и осећаји могу доћи“.” До нас је стигла слаба сенка будизма, а остао је непознат „нематеријални израз Лао-Цеа, етерична расположења Ту-Фуа, без ичег сличног код нас" и зато је једна оваква антологија неопходна. ${ }^{8}$

Црњански се трудио да преводећи кинеску поезију са француског не одузима „боју тим далеким, прастарим и нежним изразима“. Колико му је то било важно, открива податак да је на крају консултовао младе кинеске студенте да му кажу најверније преводе. "Они су са љубазношћу која је код њих вечна, нагињали се над књигама и саветовали ме.."9

Песник је желео да преведе атмосферу, смисао и садржине које се „распадају у ваздуху“, емоцију, оно непреводиво што песму чини поезијом: „А над свим тим, међу црним лаковима, зеленкастим седефима, позлаћеним тицама, сребрним шумама, превијали се бели мостови у видик, над којима је било неко провидно небо, а под њима непомичне плаве воде и мир. То је требало превести“10. Желео је да у преводима оствари девет естетичких квалтета оне резонанце, коју је Фан Вена из 11. века назвао јун, што значи да је у делу дух који траје. А ти естетички квалитети су: суптилност, узвишеност, посебност, грациозност, богатство, дубина, чврстина, чистота, древност. ${ }^{11}$

Песник „Суматре“ пише у предговору „Антологије кинеске лирике“: „Годинама сам носио, а да их нисам заборављао у духу, те тичице у снегу и расцветане гране, насликане непосредно у видик. Из небројених смешних, нетачних превода почео сам полако, тачно, да слутим гребене тих непомичнх планина, над којима је тишина. ${ }^{.12} \mathrm{He}$ само у поезији већ и у прозном стваралаштву овог уметника визуел-

7 Исто, стр.45

8 Црњански пише: „И, у Паризу, ја сам, утврдивши текст, проводио време у музејима, дуге и светле ноћи, које се из видика нису спустиле на земљу, него само на врх сребрне неке трске, на старим свилама, доводиле су ме до мирног осмеха, којим се једино може разумети текст Лао -Цеа“. (Miloš Crnjanski: Antologija kineske lirike, Čačak: Gradac, 2004, стр.50)

9 Miloš Crnjanski: Antologija kineske lirike, Čačak: Gradac, 2004, стр.49

10 Miloš Crnjanski: Antologija kineske lirike, Čačak: Gradac, 2004, стр.50 Душан Пајин: Кинеска поезија, Нови Сад:Златна греда, 6р. 121/122, 2011. стр.65. 
ни доживљаји неба, далеких предела, плавих вода, трешњиног цвета преточени су у речи, због чије лиричности поетика Црњанског је сасвим особена у нашој књижевности.

„Црњански је...у нечем другом био једини: нико пре њега у српској књижевности није са текстом кинеске лирике доживе тако узбудљив „однос“, нити га је са толико заноса описао“.13

Црњански је веровао да поезија мора да има тајанствену моћ, и он је повезивао оне најдубље слојеве Вишњића и Његоша, српских романтичарских песника са модерном поезијом и поезијом источних народа. У српским иконама и фрескама видео је корене кубизма. „Сва су песништва једно море око земље и бог животворни таласа се по њему од народа до народа“, пише 1924. године у „Нашој лирици“. Зато у тај контекст веза по сродности и тајанственом родословљу уводи егзотичну и етеричну поезију Истока, чиме његов стваралачки космос постаје светски. Обједињене тајанствене везе свега живог и постојећег и на земљи и свемиру именује далеким, егзотичним индонежанским острвом: Суматра. ${ }^{14}$ Суматра је један од најважнијих књижевних топоса српске књижевности, примећује Александар Петров. После превода кинеске и јапанске поезије, у поезији Црњанског учесталије се понављају мотиви типични за поезију ових народа: трешњин цвет ${ }^{15}$ се јавља у „Посланици из Париза“, „Стражилову“, „Ламенту над Београдом“16, „Поворци“. Црњански је открио нови ап-

13 Александар Петров: Српски модернизам: гласници, гласила, судије, Београд: Signature, 1994, стр.138

14 Александар Петров: Српски модернизам: гласници, гласила, судије, Београд: Signature, 1994, стр.133

Кајоко Јамасаки у раду „Завичај и туђина трешња и поезија Милоша Црњанског“ пише да се после антологија кинеске и јапанске поезије „слика расцветане трешње појављује као важан симболичан топос“

(Зборнк радова: Језк, књижевност и култура: Новици Петковићу у спомен, Београ: Инситут за књижевност и уметност, 2011, стр. 179)

Парис, моји мртви другови, трешње у Кини, привиђају ми се још, док овде ћутим, бдим, и мрем

и лежим, хладан, као на пепелу клада....

... Само, све то, и ја, нисмо никад ни били више, него нека пена, тренутци, шапат у Кини, што сапће, као и срце, све хладније и тише:

да не остају, ни Минг, ни јанг, ни јин, ни Тао, трешње, ни мандарин. 
солут, етеричко јединство свега постојећег, човека и природе, појава и ствари, туђине и завичаја. ${ }^{17}$

Мотив месечина и месец су после Париза постали приметнији и етеричнији у делу Црњанског, као и мотиви леда, севера, „тихих и снежних врхова Урала“. Несумњиво је да су теме старе кинеске религије и хаику поезије, где је лик „скитнице“, како је описао Башоа, чувеног песника хаику поезије, „појачао луталачке црте лирског субјекта“ српског песника, где његов „луталица има и све црте словенског занесењака који плови и лебди над рекама и облацима."

Појава „Антологије кинеске лирике“ Црњанског била је значајна за српску културу јер је нудила доказе за неопходан преокрет у тадашњој српској поезији, којој су тежили млади српски песници. Зато је одушевљено дочекао Андрића и његов „Ex Ponto“. Битка за признање покрета „младих“ тек је предстојала и многа оспоравања су морали да претрпе. Димитрије Митриновић, кога многи читају као претечу тог покрета „младих“ није био неупитан ауторитет, али класична поезија Истока, стара више од три хиљаде година ${ }^{19}$ - јесте. Обе антологије Милоша Црњанског су лепо дочекане, али су остале без оног одјека које су заслуживале. Истакнут је њен етерични лиризам, потреба да се престане са обожавањем Запада и као истински лирски зов са истока трасира пут за више „органских додира са Истоком.“20 Исидора Секулић је у „Српском књижевном гласнику“ обратила пажњу на „Антологију кинеске поезије“, похвалила напор Црњанског да представи „ту интересантну лирку далеког истока“ и истакла главну разлику између српског тадашњег песништва, које сваки

(Јан Мајен је ненастањено острво у Арктичком океану, којем је песник ишао у посету. Минг је стара династија Кине.

Јанг и Јин- мушки и женски принцип у кинеској митологији.

Тао - значи Пут; у кинеској филозофији означава законитост свемира, којим се по унутрашњој нужди креће свако светско збивање; главни филозофски принцип таоиста. Мандарини су највиши ред кинескх великодостојника и државних саветника) Милош Црњански: Ламент над Београдом, Београд: Танеси, 2010 ( слике и цртежи Момо Капор, поговор: Александар Петров: Ламент над српским Јерусалимом ), стр. 31

18 Александар Петров: Српски модернизам: гласници, гласила, судије, Београд: Signature, 1994, стр.144

19 О класичној кинеској поезији, Чачак: Градац, бр.53, 1983, стр. 38

20 Александар Петров: Српски модернизам: гласници, гласила, судије, Београд: Signature, 1994, стр.152 
осећај провлачи кроз интелект, а код песника Истока „преовлађује наговештење визије, тренут осећаја“. ${ }^{21}$

Тек у наше време ове две књиге добијају право, заслужено место у српској култури. ${ }^{22}$ Далекоистоични песнички цвет, да парафразирамо Александра Петрова, је у Црњанском имао преданог баштована, који је га је посадио у дубоку бразду књижевне њиве и огрејао сунцем свог песничког генија.

Поднебеско царство, царство трешњиног цвета српска култура дубље, свеобухватније почела је да упознаје тек после Другог светског рата. И тада се преводи кинеска књижевност са других страних језика ${ }^{23}$ да би тек последњих деценија 20. века српски синолози почели да преводе са оригинала, са кинеског језика.

Најзад, српски дух и око су могли да доживе (непреводиву) етеричну лепоту трешњиног цвета.

21 Исто, стр.152-153

22 Хироши Јамасаки Вукелић је дао кроки стилске анализе појединих препаваних стихова Црњанског, када је и сам радио антологију класичне кинеске лирике од XI века пре наше ере до краја XII века "Сто божура у врту кинеских царева“ .

Чанг Сјанг Хуa (Zhang Xianghua) је приредила „Антологију савремене кинеске поезије“, 1993. године и истакла значај Антологије ....Црњанског који „је омогућио да плодови кинеске поезије доспеју и на ове просторе, изазвавши снажан „културни шок“. Суматраизам је дубоко утицао не само на књижевност, поезију и уметност Југославије, већ је и ондашњи младих из њега црпео снагу“ ( „Антологија савремене кинеске поезије“, Београд: „Филип Вишњић“, 1994, стр 5-6)

23 Значајна је била антологија Драгослава Андрића „Свет у капи росе“, издата 1991. у Београду 
Додатак: Хронологија објављених дела о Кини (путописи, поезија, пословице...):

\section{1-1941}

1. Сербски народни лист, 1841

2. Србске новине, додатак Подунавка, 1844-1858

3. Пештанско-будимска скоротеча, 1844

4. Јовановић, Милан: Тамо амо по Истоку,1895

5. Војно-географски поглед Маниурије, 1905

6. Суботић, Озрен Ј.:Из жутог царства, 1921

7. Црњански, Милош: Антологија кинеске поезије, 1923

8. Раосављевић, Паја: Дух кинеске културе и цивилизације, 1923

9. Радек, Карло: Револуција у Кини, 1926

10. Миланковић, ДЈ: Успомене из Сибира 1918-1919, 1926

11. Ангелов, Никола: Соја : Кинески пасуљь : будућа храна човечанства,1929

12. Велимировић, Милутин: Кроз Кину,1930

13. Рајчевић, Милорад: На Далеком Истоку, 1930

14. Велимировић, Јелена: Једна Српкиња на Далеком истоку; и На најлепшој кинеској плажи Цингтао (Време, 1932)

15. Горјан, Златко: Лирика жутог Истока,1932

16. Диклић, Славко: Путничке биљешке југословенског ратног добровољиа, 1932

17. Кинеске и јапанске бајке, 1934

18. Станојевић, Влада: Моје ратне белешке, 1934

19. Милићевић, Александар: Кратак увод у источне књижевности, 1935

20. Ђорђевић, Јован: Савремена Кина као држава ,1937

21. Еренштајн, Алберт: Šui Hu Čuan, 1937

22. Петковић, Живко Д.: Кина, 1937

23. Ђурић, Александар: Ка победи/ратни дневник/, 1938

24. Махин, Фјодор: Кина у пламену, 1939

25. Чугујев, Т. К.: Pestaloci i problemi vaspitanja, 1939 


\section{Извори и литература:}

Андрић, Драгослав: Свет у капи росе, Београд, 1991

Gorjan, Zlatko: Lirika žutog istoka, Zagreb, 1932

Јамасаки Вукелић, Хироши: Сто божура у врту кинеских царева: класична кинеска лирика од XI века пре наше ере до краја XII века, Београд:JМУ РТС, 2015

Јамасаки, Кајоко: Завичај и туђина трешња и поезија Милоша Црњанског у: Зборник радова: Језик, књижевност и култура: Новици Петковићу у спомен, Београд: Институт за књижевност и уметност, 2011

О класичној кинеској поезији, Чачак: Градац, 1983 бр.53

Пајин, Душан : Кинеска поезија, Нови Сад:Златна греда, бр. 121/122, 2011.

Петров, Александар: Српски модернизам: гласници, гласила, судије, Београд: Signature, 1994

Пештанско-будимска скоротеча, Пешта, бр.11, 1844

Поднебеско царство: Срби о Кини 1725-1940 (путописи и чланци), приредио Радосав Пушић, Београд: Чигоја штампа, 2006

Прилози за израду кинеске библиографије, приредили: Здравка Радуловић, Бранислав Ристић, Небојша Ковачевић, Београд: Народна библиотека Србије, 2014

Сербски народни лист(Сербскій народный листь), число 37, 1841

Србске новине, додатак Подунавка, Београд, 1844

Crnjanski, Miloš: Antologija kineske lirike, Čačak: Gradac, 2004

Црњанск, Милош : Песме старог Јапана, Београд-Сарајево: Напредак, 1928

Црњански, Милош: Ламент над Београдом, Београд: Танеси, 2010

Чанг Сјанг Хуа (Zhang Xianghua) : Антологија савремене кинеске поезије, Београд: „Филип Вишњић“, 1994 


\section{Milanka Babic Vukadinov}

\section{CHERRY FLOWER IN SERBIAN EYE (WINDOW)}

\section{Summary}

The first words about Chinese literature in Serbian culture were written in the Church Slavonic language in 1841 and published in the Сербском народном листу, in Budim. In the 19th century (1843 and 1844), two more short texts on Chinese literature were published, so that in 1923, through Paris, with the Anthology of the Chinese poetry of Milos Crnjanski, the Serbian culture had an exciting and intertwining encounter with cultural creativity Chinese spirit.

Until the Second World War, only two other anthologies of Chinese literature were in front of our readers: The Liquid of the Yellow East by Zlatko Gorjana (1932) and the Chinese and Japanese Fairy Tales (1934).

Key words: Chinese literature in Serbian language,China- Serbian travelogue, Milos Crnjanski. 